\title{
SPIN-ORBIT COUPLING EFFECTS IN O ACTIVATION BY COFACTOR-INDEPENDENT 2,4-DIOXYGENASE
}

\author{
B. F. MINAEV $V^{1}$, R. R. VALIEV ${ }^{2}$ \\ ${ }^{1}$ Bohdan Khmelnytsky National University of Cherkasy, Ukraine; \\ e-mail:bfmin43@ukr.net; \\ ${ }^{2}$ Royal Institute of Technology, Stockholm, Sweden; \\ e-mail:valievrashid@mail.ru
}

Received: 22 August 2018; Accepted: 13 December 2018

The $\mathrm{O}_{2}$ (dioxygen) is paramagnetic molecule with two non-paired electron spins and triplet ground state $(S=1)$ while majority of organic molecules are diamagnetic species; they have all electron spins paired and the singlet ground state with the total spin $S=0$. Oxygenases catalyze a concerted insertion of the triplet dioxygen into organic (diamagnetic) molecules in a strictly spin-forbidden process and this puzzle is not solved so far in modern enzymology. Many oxidases and oxygenases utilize the $\pi$-conjugated organic cofactor (like flavins, pterins) in a singlet ground state and reaction of cofactor with $\mathrm{O}_{2}$ is still spin-forbidden. It is clear that the protein environment in the enzyme active-site "helps" in some way to overcome spin prohibition, but this environment is definitely diamagnetic and the spin-puzzle still exists. Some oxidases and oxygenases use paramagnetic metal ions as a cofactor; in this case the spin prohibition is formally reduced. In recent years, a numbers of oxidative enzymes are discovered which do not contain any cofactor. In the present work, we considered a rather popular cofactor-free bacterial 2,4-dioxygenase and its oxygenolytic reactions with 2-nalkyl-3-hydroxy-4(1H)-quinolones (AHQ's). We presented results of quantum-chemical calculations of intermediate diradical proposed recently for direct reaction of dioxygen with AHQ substrate and made conclusion about the mechanism of spin-catalysis.

Ke ywords: dioxygen, spin-orbit coupling, cofactor-independent oxygenases, superoxide anion, tripletsinglet transition, bacterial 1-H-3-hydroxy-4-oxoquinaldine 2,4-dioxygenase, 2-methyl-3-hydroxy-4(1H)-quinolone, radical pair.

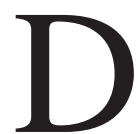
ioxygen $\left(\mathrm{O}_{2}\right)$ possesses the triplet ground state $\mathrm{X}^{3} \Sigma_{\mathrm{g}}^{-}$, which implies strong quantum restrictions on its spectra and biochemical reactivity [1-10]. The whole aerobic life strongly depends on the kinetic barriers to dioxygen reactions; $\mathrm{O}_{2}$ is used as an oxidant in respiration of mammals reducing food to water and carbon dioxide and in many oxidative metabolic processes distributed from bacteria to human. Typically dioxygen in its ground triplet state is chemically non-reactive to organic substrates, because $\mathrm{O}_{2}$ reaction with the singlet-state organic molecule to form diamagnetic products is strictly spin-forbidden [1-4]. This is due to quantumchemical reasons determined by pure quantum nature of the spin notion [10]. In this sense oxidative enzymology is a pure quantum-chemical science, though experimentalists do not like to discuss spins $[3,4]$. Oxygenase enzymes can effectively catalyze $\mathrm{O}_{2}$ reactions which appear to the normal chemical intuition as very strange and exotic [4]. At least, they seem impossible in synthetic chemical laboratory.

The present work is devoted to the spin-selection rule analysis for some particular dioxygenases which were recently discovered in bacteria [11-18]. Dioxygenases catalyze incorporation of two oxygen atoms from $\mathrm{O}_{2}$ into their organic substrates as a remedy to initiate metabolism [12]. These enzymes provide key functions for human health and were used in development of antitumor therapy [13]. They are also important for plants participating in

(c) 2019 Minaev B. F., Valiev R. R. This is an open-access article distributed under the terms of the Creative Commons Attribution License, which permits unrestricted use, distribution, and reproduction in any medium, provided the original author and source are credited. 
signaling functions [11, 13]. Bacterial dioxygenases are interesting for biotechnology being involved in harmful substances biodegradation [13]. Thus, the problem to overcome spin prohibition in $\mathrm{O}_{2}$ activation by these enzymes is of very general importance for biology.

Typically, oxygenases use cofactor in the form of transition metal or highly unsaturated dyes (like flavins, folates or pterins) with particular redox properties. The reduced cofactor is a prerequisite for efficient oxygenolysis. During last two decades several oxygenases have been discovered which do not contain any cofactor [11-21]. This stresses the problem of spin prohibition overcoming and raises the general question of how such enzymes do activate dioxygen.

Cofactor-free oxygenases. One of the first cofactor-independent enzymes was identified by Shen et al. [20]. It was the tetracenomycin F1 monooxygenase (TcmF1) being involved in biosynthesis of aromatic polyketides [20]. Shen et al. also proposed the first mechanism of cofactor-free oxygenation for the TcmF1 example [20]. It assumes the substrate and protein radicals formation before $\mathrm{O}_{2}$ activation [20]. This mechanism seems to be unreliable because of high activation energy barrier.

A large number of cofactor-free oxygenases were identified and carefully studied quite recently [11-19]. The most popular among them and the most studied is the bacterial 1-H-3-hydroxy-4-oxoquinaldine 2,4-dioxygenase (HOD) [11]. This cofactorfree enzyme catalyzes the triplet dioxygen reaction with oxoquinolone substrates of the AHQ family [12-14]. HOD from Arthrobacter nitroguajacolicus Rü61a [11] degrades AHQ substrates and produces carbon(II) oxide and anthranilates. In this paper we shall calculate the HOD reaction with $\mathrm{O}_{2}$ and substrate: 2-methyl-3-hydroxy-4(1H)-quinolone (MHQ) [13]. Oxygenolyses of MHQ by HOD produces CO + N-acetyl-anthranilate (NAA) products, Eq. (1).

The structure of HOD has been studied by $\mathrm{X}$-ray crystallography analysis in the native state as well as in the complex with its natural MHQ substrate [15]. The structures of HOD complex with the NAA reaction product, and with chloride as dioxygen mimic, have also been studied. All these structures have been used in DFT simulations of the catalytic reaction path [12-14]. We also use these structures in our DFT geometry optimizations.

Detailed DFT calculations [13] show the role of the nearest protein environment of HOD enzyme<smiles>Cc1[nH]c2ccccc2c(=O)c1O</smiles>

MHQ

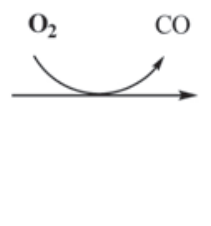

HOD<smiles>CC(=O)Nc1ccccc1C(=O)O</smiles>

NAA in catalysis of reaction (1). The most important is hystidine residue, $\mathrm{His}_{102}$, in the active-site acidic dyad His ${ }_{102}, \mathrm{Asp}_{126}$ [15]. At the first stage of reaction (not shown in Scheme 1) a proton from $\mathrm{O}^{3} \mathrm{H}$ group of MHQ substrate (1) is transferred to hystidine residue $\left(\mathrm{His}_{102}\right)$ of enzyme [11-15]. Thus, the substrate $\mathrm{SH}$ (denoted MHQ) became $\mathrm{S}^{-}$anion and this is the starting point in the reaction mechanism (Scheme 1).

At the same time the $\mathrm{O}^{4}$ atom is additionally stabilized by interaction with $\mathrm{OH}$ group of the $\mathrm{Ser}_{101}$ residue [13]. In the HOD protein scaffold the first acidic dyad $\mathrm{His}_{102}$, Asp ${ }_{126}$ together with $\mathrm{Ser}_{101}$ residue form an important catalytic triad which plays a crucial role in stabilization and activation of substrate $[13,15]$. In Scheme 1 the resting state $\left({ }^{3} \mathbf{R}\right)$ of catalysis is shown as the first step when dioxygen enters the active site of HOD. Deprotonated MHQ (S- singlet anion) can provide electron transfer to $\mathrm{O}_{2}$ and from this point we have two different opportunities. Only one of them is shown in Scheme 1, being established by DFT calculations [13].

According to [13] a direct $\mathrm{O}_{2}$ attack on substrate $\mathrm{S}^{-}$anion leads to a covalently-bound ${ }^{3} \mathbf{I}_{1}$ triplet intermediate through a large barrier of $17.4 \mathrm{kcal} / \mathrm{mol}$.

The spin inversion between ${ }^{3} \mathbf{I}_{\mathbf{1}}$ and ${ }^{1} \mathbf{I}_{1}$ would occurs at the minimum energy crossing point (MECP) [13]. The authors [13] did not achieved the MECP optimization and did not conclude about the driving force for T-S transition. But they insist on the direct oxygen attack mechanism shown in Scheme 1.

The other mechanism proposed by Fetzner et al. [15-18] includes electron transfer from reduced substrate $\mathrm{S}^{-}$to $\mathrm{O}_{2}$ and the triplet radical pair formation between subatrate radical $\left(\mathrm{S}^{\circ}\right)$ and superoxide $\left(\mathrm{O}_{2}^{-{ }^{-}}\right)$ anion-radical (instead of covalently-bound ${ }^{3} \mathbf{I}_{1}$ intermediate in Scheme 1). This radical pair $\left(\mathrm{S}^{\cdot} \ldots \mathrm{O}_{2}^{-{ }^{-}}\right)$ initially formed in the triplet state (not shown in Scheme 1) undergoes the triplet-singlet (T-S) transition by analogy with the well-known mechanism of Massey [22] for flavin-containing oxygenases and then recombines into the proposed peroxide intermediate ${ }^{1} \mathbf{I}_{1}$ [18]. 


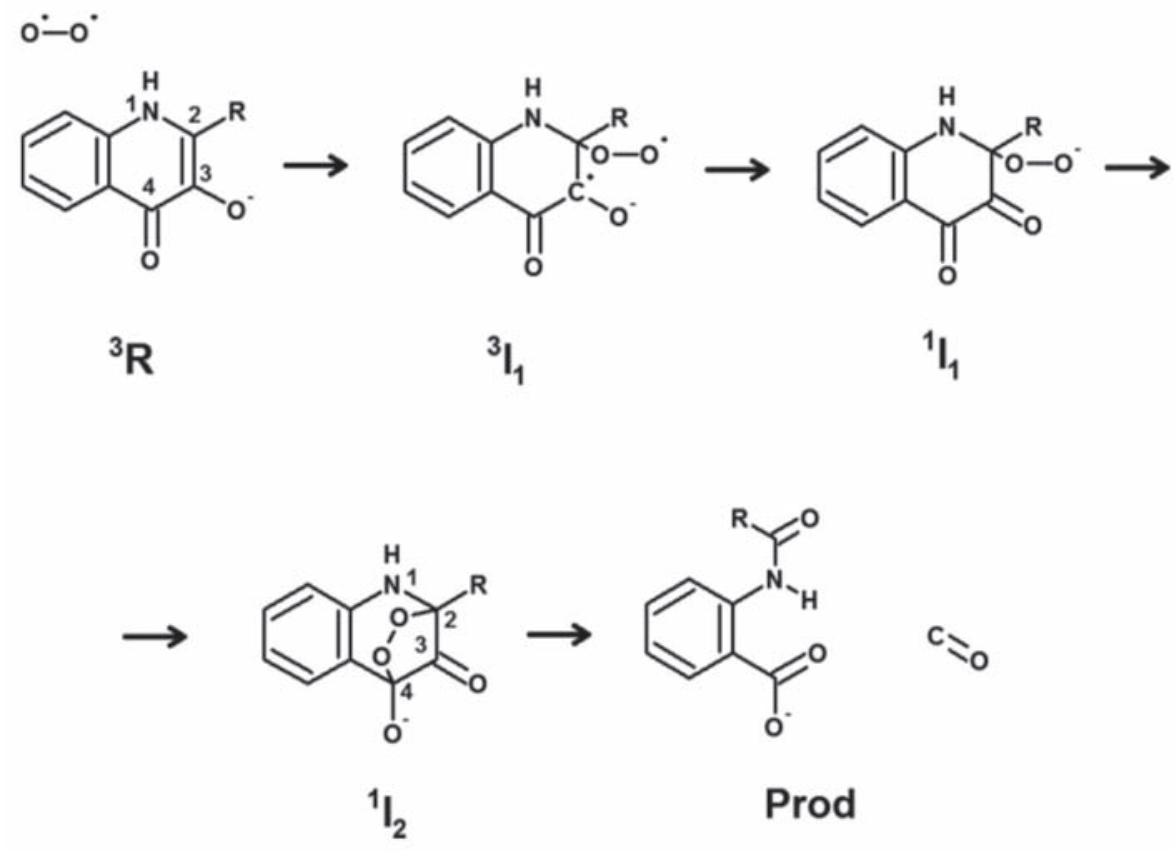

Scheme 1. The mechanism of HOD reaction with 2-n-alkyl-3-hydroxy-4(1H)-quinolones proposed in [13] (A substituent $\mathrm{R}=\mathrm{CH}_{3}$ corresponds to our MHQ substrate). The scheme is borrowed from P.J. Silva [14] with permission

Vincent Massey generalized reactivity of reduced flavins in solvents, Eq. (2) [22] for many oxygenases.

$\mathrm{Fl}_{\text {red }} \mathrm{H}^{-}(\uparrow \downarrow)+\mathrm{O}_{2}(\uparrow \uparrow) \rightarrow\left[\mathrm{FlH}^{\bullet} \uparrow \uparrow \mathrm{O}_{2}^{-\bullet}\right] \rightarrow$ $\rightarrow\left[\mathrm{FlH}^{\cdot} \uparrow \downarrow \mathrm{O}_{2}^{-*}\right] \rightarrow \mathrm{FlHOO}^{-} \stackrel{+H^{+}}{\longleftrightarrow} \mathrm{FlHOOH}$

Here the spin-flip mechanism in the radical pair between flavin semiquinone radical and superoxide ion was postulated, probably, on the ground of radical pair theory (RPT) [23]. Though Eq. (2) was proposed for free flavins initially reduced in solvents it was thought to be applied for all $\mathrm{O}_{2}$-activating enzymes which contain flavin cofactor [22].

The weak point here is connected with the nature of driving force for the spin flip in Eq. (2). Massey made no comments about this. One can propose logically that Massey has taken into account the ideas of RPT [23] which were popular that time. The square brackets in Eq. (2) denote the solvent cage for radical pair which is really big and embraces a micro-part of solvent volume [23]. It means that two radicals can be far separated before their secondary collision and spin evolution proceeds during free diffusion of radicals inside solvent cage between two collisions. According to RPT the driving force for spin inversion in such radical pair is represented by very weak electron-nuclear spin-spin interaction (hyper-fine coupling, $10^{-4} \mathrm{cal} / \mathrm{mol}$ ) inside each radical [23] being additional reason for external magnetic field effects [24]. By no means RPT can be applied neither to flavoenzymes no cofactor-free oxygeanses, since the enzyme active cite is very limited in space. Of course, some limited diffusion is possible (otherwise $\mathrm{O}_{2}$ would never penetrate the enzyme active cite) but secondary collisions in the flavoprotein cage are not likely. Thus, the RPT arguments with their driving force for spin inversion can not be accepted for enzymes. This could be an additional argument against the "substrate-assisted" mechanism and electron-transfer concept of Fetzner et al. [16-18] being in favour of direct dioxygen attack proposed by Hernandez-Ortega et al. [13].

Contrary to these arguments, in the present paper we want to discard conclusions of Ref. [13] and support the electron-transfer concept of Fetzner et al. [16] on the ground of the MECP calculation and magnetic forces responsible for T-S transition.

\section{Method of Calculations}

We have started with the optimized geometry of the ${ }^{3} \mathbf{I}_{\mathbf{1}}$ triplet intermediate (Scheme 1) published in supplementary [13]. We have recalculated ${ }^{3} \mathbf{I}_{1}$ structure by the density functional theory (DFT) with the B3LYP functional $[25,26]$ and 6-31 G(d,p) basis set [26] by spin-unrestricted DFT method for the triplet state. The minimum energy crossing point has been 
found using method of Harvey et al. [27]. It means that the complete active space self-consistent field (CAS SCF) method was applied to find MECP geometry using various active spaces. The best conical intersection was obtained with the $(16,11)$ CAS, which includes 16 electrons in 11 orbitals (8 occupied and 3 unoccupied MO's). This choice is reasonable since only 3 MOs, discussed below, are the most important in the CAS wave-functions.

The MECP was optimized using a steepest-descent approach [27] with the difference of the energy gradients derived from state-averaged CAS SCF calculations. These gradients were minimized for both $\mathrm{T}$ and $\mathrm{S}$ states first. The MECP was characterized as a minimum on the crossing seam between $\mathrm{T}$ and $S$ potential energy surfaces by diagonalization of the projected effective Hessian matrix [27]. On the found MECP geometry we also made a single-point CASPT2 calculation with better account of dynamic correlation effects [28]. CASPT2 was realized in the form of extended multiconfiguration quasi-degenerate method at the second order of perturbation theory (XMC-QDPT2) [30].

The SOC matrix elements between the singlet state wave-function and each spin sub-level of the triplet state were calculated using the CASSCF and XMC-QDPT2 wave-functions. We used an effective single-electron approximation for SOC operator with specially calibrated nuclear charges for spin-other orbit interaction account as it was implemented in the GAMESS (US) program [29]. All calculations were done with the Firefly quantum chemistry code made in MGU by Granovsky[28]. Firefly package is partially based on the GAMESS program [29] but includes modern versions of CASPT2 - (XMCQDPT2) method for open shell calculations.

\section{Results and Discussions}

The new mechanism of HOD catalysis for oxygenolytic breakdown of the quinolone substrates (Scheme 1), proposed by Hernandez-Ortega et al. [13], considers a direct $\mathrm{O}_{2}$ attack on substrate $\mathrm{S}^{-}$anion ( ${ }^{3} \mathbf{R}$ step) leading to a covalently-bound ${ }^{3} \mathbf{I}_{1}$ triplet intermediate which undergoes T-S transition into its singlet ${ }^{1} \mathbf{I}_{1}$ counterpat. The authors did not succeed in optimization of the minimum energy crossing point (MECP) between $\mathrm{T}$ and $\mathrm{S}$ hypersurfaces and did not calculate the driving force for T-S spin inversion [13]. They rejected the electron-transfer mechanism of Fetzner et al. $[16,18]$, which is analogous to dioxygen activation by flavoenzymes, Eq. (2) [22], where the radical pair $\left(\mathrm{S}^{-} \ldots \mathrm{O}_{2}^{-*}\right)$ is formed in the HOD cavity and the T-S transition occurs inside this RP. Both theories [13] and [18] say nothing about the magnetic force nature responsible for the spin flip.

Hernandez-Ortega et al. [13] refused from the electron-transfer mechanism [16] because they did not succeed in calculation of radical pair $\left(\mathrm{S}^{\cdot} \ldots \mathrm{O}_{2}^{--}\right)$ inside the studied models of the HOD cavity. Different number of amino-acid residues were simulated based on the X-ray analysis of HOD (all include the important catalytic triad $\mathrm{His}_{102}, \mathrm{Asp}_{126}$ and $\mathrm{Ser}_{101}$ and other residues in vicinity of substrate $\mathrm{S}$ ) $[12,13]$, but the reaction (3) was not supported by DFT calculations [13].

$$
{ }^{3} \mathbf{R}\left(\mathrm{S}^{-}+{ }^{3} \mathrm{O}_{2}\right) \rightarrow\left(\mathrm{S}^{\cdot} \ldots \mathrm{O}_{2}^{-\bullet}\right)
$$

The UB3LYP optimization converges to the ground state that is better assigned as ${ }^{3} \mathbf{R}$ in Scheme 1. But some spin transfer was still observed; spin density of 1.6 on dioxygen moiety and 0.4 on the substrate were fixed for ${ }^{3} \mathbf{R}$ model in enzyme [13]. This means that with better protein arrangement and more correlated wave-functions the larger spin density transfer, close to Eq. (3) could be achieved.

The energy arguments against electron transfer (3) are also not fully convincing [13]. Account of solvent correction in DFT method with dielectric permittivity $(\varepsilon=5.7)$ provides the Gibbs energy for reaction (3) equal to $\Delta \mathrm{G}_{\mathrm{eq} 3}=11.2 \mathrm{kcal} / \mathrm{mol}$, whereas account of water $(\varepsilon=78)$ leads to $\Delta \mathrm{G}_{\text {eq3 }}=8 \mathrm{kcal} /$ mol [13]. This endothermic barrier is not so big like the activation barrier for ${ }^{3} \mathbf{I}_{\mathbf{1}}$ intermediate production $(17.4 \mathrm{kcal} / \mathrm{mol})$ in Scheme 1.

The self-consistent field methods are known [14] to meet convergence problems when they attempt to reproduce radical pair structure (3) lying at higher energy than the simple ${ }^{3} \mathbf{R}$ alternative (with singlet closed-shell S- substrate and the clear triplet $\mathrm{O}_{2}$ wave-functions). The difficulty with convergence achievement is not an indication of the intrinsic instability of the $\left(\mathrm{S}^{\cdot} \ldots \mathrm{O}_{2}^{--}\right)$radical pair in the HOD cavity. Thus, P. Silva has analyzed the kinetic and thermodynamic parameters of reactions (3) using the Marcus theory [14], which is based on separate calculations of the donor and acceptor energies. Silva has calculated radical pairs for various quinolones $\left(\mathrm{R}=\mathrm{F}, \mathrm{COH}, \mathrm{NO}, \mathrm{CN}, \mathrm{NO}_{2}, \mathrm{NH}_{2}, \mathrm{COO}^{-}, \mathrm{CH}_{3}\right.$ in Scheme 1) with superoxide at 2-12 $\mathrm{nm}$ distances [14]. The calculated rate constants for electron transfer (ET) reactions (3) exceed $0.1 \mathrm{~s}^{-1}$. Comparison of these reaction and activation energies to the energy 
of MECP (or the ${ }^{3} \mathbf{I}_{\mathbf{1}}$ intermediate energy [13]) indicates that ET reaction with the MHQ substrate is favored over reaction through MECP by more than $8 \mathrm{kcal} / \mathrm{mol}$ [14]. Thus, Silva comes to conclusion that generation of the ${ }^{1} \mathbf{I}_{1}$ intermediate can proceed through the triplet state ET reaction (3) with subsequent T-S transition at the $\left(\mathrm{S}^{-} \ldots \mathrm{O}_{2}^{-*}\right)$ radical pair stage and recombination of radicals in agreement with Fetzner mechanism [16-18].

The driving force for the spin flip in cofactorindependent enzymes was considered $[14,21]$ to be spin-orbit coupling (SOC) as it was proposed for the first time for oxidases containing flavin cofactor $[1,7]$. The SOC mechanism was also proved to be correct for explanations of many optical and chemical properties of dioxygen [1-10] and its application for $\mathrm{O}_{2}$ activation by cofactor-free dioxygenases will be considered later at the final conclusions of this paper.

Now we want to check applicability of the whole mechanism (Scheme 1) proposed by [13] and to calculate MECP for SOC estimation at the ${ }^{3} \mathbf{I}_{1} \rightarrow$ ${ }^{1} \mathbf{I}_{\mathbf{1}}$ transition. Direct dioxygen attack on $\mathrm{C}^{2}$ atom of substrate MHQ leads to a C-O bond formation and T-S transition has to occur at this stage (Scheme 1) [13].

The minimum energy crossing point between the ${ }^{3} \mathbf{I}_{1}$ and ${ }^{1} \mathbf{I}_{1}$ potential energy surfaces optimized by the Harvey algorithm [27] with the CASSCF $(16,11) / 6-31 G(d, p)$ method is presented in Fig. 1. The state-averaged molecular orbitals which determine mostly the open-shell wave-functions of the $\mathrm{T}$ and $\mathrm{S}$ states are shown in Fig. 2. One should note that the MECP energy and the structure of the intersecting $\mathrm{T}$ and $\mathrm{S}$ states wave-functions strongly depend on the active space choice, but geometry of nuclear displacement is more-or-less constant and corresponds to peroxo compounds in $\mathrm{T}$ and $\mathrm{S}$ states shown in Scheme 1. Even the covalent structure of ${ }^{3} \mathbf{I}_{1}$ peroxydiradical is rather different from the closed-shell singlet state of peroxide intermediate ${ }^{{ }^{1}} \mathbf{I}_{\mathbf{1}}$. The MECP structure is rather similar to the local minimum of the ${ }^{3} \mathbf{I}_{1}$ state. The triplet ${ }^{3} \mathbf{I}_{1}$ looks like diradical with one non-paired electron on the peroxo-O-O group (local radical center on the terminal atom with spin density 0.7 and spin 0.3 at the distal atom) and the second non-paired electron being delocalized in the ring (spin density on carbon atoms $\mathrm{C}^{4}$ and $\mathrm{C}^{3}$ is equal 0.24 and 0.15 , on $\mathrm{O}^{4}$ and $\mathrm{O}^{3}$ oxygen atoms -0.21 and 0.29 , respectively). Thus, the shown ${ }^{3} \mathbf{I}_{1}$ structure in Scheme 1 does not fully correspond to the calculated spin density distribution.

The MECP structure (Fig. 1) is rather similar to the ${ }^{3} \mathbf{I}_{1}$ diradical intermediate calculated [13, 14]. The substrate-oxygen bond (1.499 $\AA$ ) is the same; the O-O bond is shorter in MECP (1.35 $\AA$ ) than in diradical (1.38 $\AA$ ) [13] being more close to free superoxide (1.334 $\AA$ ). In the singlet state ${ }^{1} \mathbf{I}_{1}$ some electron transfer from the $\mathrm{O}^{3}$ atom occurs to the terminal oxygen of peroxo-group in agreement with the simplified covalent structures of Scheme 1. In the triplet state the $\pi_{p}-\pi_{1}$ configuration dominates with small admixture of the $\pi_{p}-\pi_{2}$ configuration wavefunction. The CAS structure of the singlet state is more complicated and includes some contributions from the closed shells.

At the CASSCF optimized geometry of the minimum energy crossing point we have recalculated the wave-functions and energies of a number of states with the extended multi-configuration XMC-

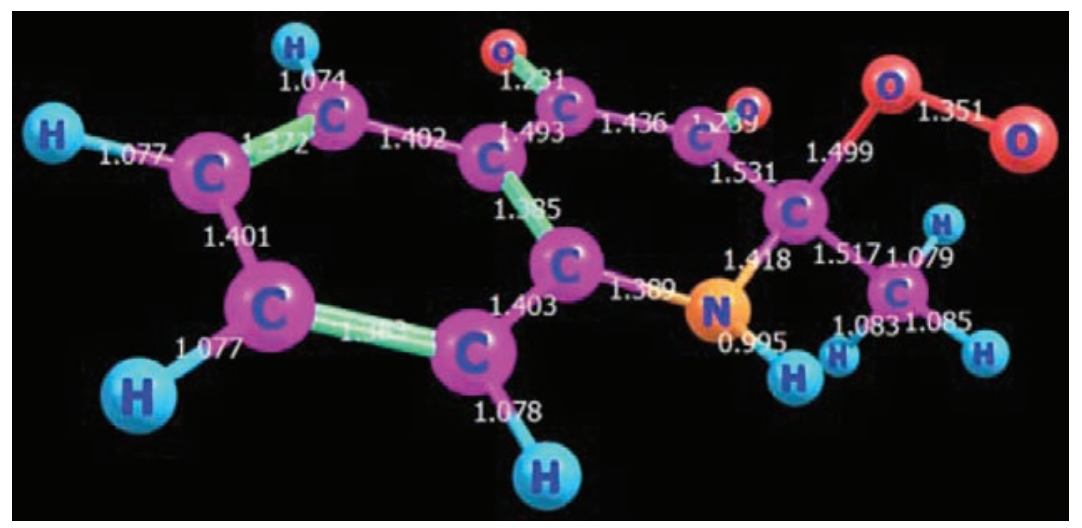

Fig. 1. Optimized structure of the MECP for the ${ }^{3} \mathbf{I}_{\mathbf{1}} \rightarrow{ }^{1} \mathbf{I}_{\mathbf{1}}$ transition with the CASSCF $(16,11) / 6-31 G(d, p)$ method 

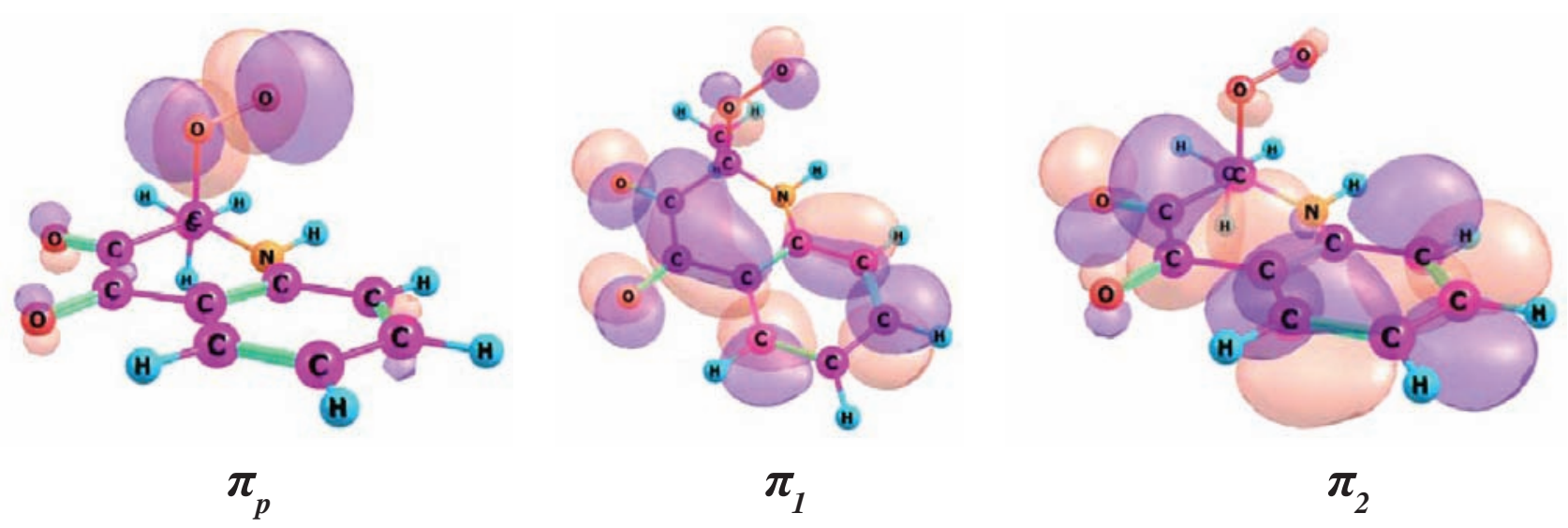

Fig. 2. The most important molecular orbitals for the $S$ and $T$ states description at the MECP geometry

QDPT2 method [30] in order to obtain the most accurate account of electronic correlation effects for quasi-degenerate states. Now the lowest $\mathrm{S}$ and $\mathrm{T}$ states have different energies (Table), but their energy gap is only $630 \mathrm{~cm}^{-1}(0.078 \mathrm{eV})$, which is practically negligible at the energy scale of Table. Thus, we have calculated the SOC matrix elements with this CASSCF and XMC-QDPT2 methods.

At the MECP geometry the orbital structures of the $\mathrm{S}$ and $\mathrm{T}$ states are only partly different which leads to a relatively small SOC integral for the $M_{s}=0$ spin sublevel $w^{0}=<\mathrm{T}^{0}\left|\mathrm{H}_{\mathrm{so}}\right| \mathrm{S}>=2.2 \mathrm{~cm}^{-1}$. The other spin sub-levels have even smaller SOC constants: $1.45 \mathrm{~cm}^{-1}\left(\mathrm{M}_{\mathrm{s}}=1\right)$ and $0.67 \mathrm{~cm}^{-1}\left(\mathrm{M}_{\mathrm{s}}=-1\right)$. This leads to the total SOC constant $|w|^{2}=7.39 \mathrm{~cm}^{-2}$, which can be used in the rate constant calculation [1-3]. With account of Landau-Zener theory for non-adiabatic T-S transition [7] at the minimum energy crossing point and the activation energy to reach MECP [14] we have estimated the rate constant $\left(3.6 \times 10^{1} \mathrm{~s}^{-1}\right)$, which could be the upper limit for observed reaction. But this rate is too low for experimentally measured kinetics [13, 18].

In order to have a large SOC matrix element between $\mathrm{T}$ and $\mathrm{S}$ states their orbital structures should be different by symmetry elements which correspond to rotation around axes. The $\pi_{p}$ orbital (Fig. 2) is mostly localized on dioxygen, but $\pi_{1}$ and $\pi_{2}$ MO's are delocalized as $\pi$-conjugations in the rings. Onecenter SOC contribution on dioxygen moiety which include orbital rotation is rather small (Fig. 2), thus the MECP structure (Fig. 1) is not favored for strong magnetic perturbation and can not provide an efficient spin flip.

Electron transfer step and formation of radical pair with superoxide ion was proved by direct
DFT calculations of glucose oxidase (GO) enzyme during its oxidative half-reaction [7]. The maximum large SOC in such radical pair of the type (2) was explained by specific orbital structure of the superoxide ion and its rotation upon T-S transition [1]. The $\mathrm{T}$ and $\mathrm{S}$ states in this radical pair can be denoted by the following orbital structures [7]

${ }^{\mathrm{T}}\left\{\mathrm{FADH}_{2}{ }^{+}[\uparrow]^{\cdot} \ldots\left[[\downarrow \uparrow][\uparrow] \mathrm{O}_{2}^{-*}\right\}\right.$ and
$\mathrm{s}\left\{\mathrm{FADH}_{2}^{+}[\uparrow]^{\circ} \ldots[\downarrow][\uparrow \downarrow] \mathrm{O}_{2}^{-\cdot}\right\}$.

The curly brackets here denote the cage cavity of the enzyme active site and the square brackets denote MOs. The first square bracket corresponds to the highest occupied MO of reduced flavin adenine dinucleotide and two square brackets of dioxygen represent the doubly degenerate $\pi_{g, x}$ and $\pi_{g, y}$ orbitals oriented in the mutually perpendicular directions [2]. The T-S transition in Eq. (4) corresponds to

States energy $\left(\mathrm{cm}^{-1}\right)$ obtained at the MECP geometry with the CASPT2 (XMC-QDPT2) method

\begin{tabular}{c|c}
\hline State & Energy \\
\hline S0 & 0 \\
S1 & 3839 \\
S2 & 11255 \\
S3 & 17679 \\
S4 & 25546 \\
\hline T1 & 630 \\
T2 & 9727 \\
T3 & 17708 \\
T4 & 23824 \\
T5 & 26743 \\
\hline
\end{tabular}


one-electron jump between these MOs which means a rotation of "electron cloud" around dioxygen molecular axis $z$. Such rotation creates a large orbital angular momentum which interacts with spin moment and induces the spin flip [2, 3]. The SOC matrix element between $\mathrm{T}$ and $\mathrm{S}$ states in Eq. (4) is equal to the maximum possible SOC value $w=i \varsigma_{O} / 2$ [1-3], where $\varsigma_{O}$ is a SOC constant for oxygen atom determined from atomic spectra $\left(\varsigma_{O}=154 \mathrm{~cm}^{-1}\right)$ [2]. With such SOC estimation $\left(w^{2}=5929 \mathrm{~cm}^{-2}\right)$ the rate constant of T-S transition $\left(10^{4}-10^{6} \mathrm{~s}^{-1}\right)$ is quite competitive with other possible processes in the cage of enzyme [5-7] and the electron transfer theory seems highly likely. The same type of spin-flip mechanism can be realized in the studied HOD 2,4-dioxygenase with the MHQ substrate cleavage to $\mathrm{CO}$ and $\mathrm{N}$-acetyl-anthranilate products, Eq. (1), if we accept the Fetzner's scheme of electron transfer from deprotonated substrate anion ( $\left.\mathrm{S}^{-}\right)$to dioxygen, Eq. (3). This scheme is supported by DFT studies [14] and by our multiconfigurational calculations of the minimum energy crossing point at the stage of ${ }^{3,1} \mathbf{I}_{1}$ intermediate in Scheme 1, proposed by HernandezOrtega et al. [13]. The calculated SOC at this stage is too low and can not provide a competitive rate for T-S transition.

Conclusions. The electron-transfer mechanism of Fetzner et al. [16-18] provides an efficient tripletsinglet transition at the stage of radical pair, Eq. (3), because of large SOC in superoxide anion $\mathrm{O}_{2}^{-\bullet}$. The SOC between T and S states in Eq. (4) does not depend on the spin of flavin cofactor and can be applied for cofactor-independent oxygenases (FAD cofactor can be equally substituted by substrate). After the T-S transition at the electron-transfer stage, Eq. (3), and generation of the ${ }^{1} \mathbf{I}_{1}$ peroxy-intermediate the reaction follows the path shown in Scheme 1 [13]. All DFT calculations of Hernandez-Ortega et al. [13] after this point (for ${ }^{1} \mathbf{I}_{2}$ intermediate and for products) provide rather low activation barriers. Thus, they are very reasonable and correctly elucidate the rest of the singlet reaction mechanism for substrate decomposition by HOD 2,4-dioxygenase [14].

Conflict of interest. Authors have completed the Unified Conflicts of Interest form at http:// ukrbiochemjournal.org/wp-content/uploads/2018/12/ coi_disclosure.pdf and declare no conflict of interest.

\section{ЕФЕКТИ СПІН-ОРБІТАЛЬНОЇ ВЗАСМОДІї ЗА АКТИВАЦЇ̈ О КОФАКТОРНЕЗАЛЕЖНОЇ 2,4-ДІОКСИГЕНАЗИ}

\author{
Б. П. Мінаєв ${ }^{1}$ Р. Р. Валієв
}

\author{
1Черкаський національний університет \\ імені Богдана Хмельницького, Україна; \\ e-mail: bfmin43@ukr.net; \\ ${ }^{2}$ Королівський технологічний \\ інститут, Стокгольм, Швеція; \\ e-mail: valievrashid@mail.ru
}

Кисень $\left(\mathrm{O}_{2}\right)$ є парамагнітною молекулою 3 двома неспареними електронними спінами та триплетним основним станом $(\mathrm{S}=1)$, тоді як більшість органічних молекул діамагнітні; вони мають спарені електронні спіни та синглетний основний стан 3 повним спіном $\mathrm{S}=0$. Оксигенази каталізують введення триплетного кисню в органічні (діамагнітні) молекули в ході строго заборонених за спіном процесів і цю загадку досі не вирішено в сучасній ензимології. Багато оксидаз та оксигеназ використовують спряжені органічні кофактори (подібно до флавінів, птеринів) у синглетному основному стані, і реакція кофактора 3 $\mathrm{O}_{2} \in$ також заборонена за спіном. Зрозуміло, що протеїнове оточення в активному центрі ензиму якимсь чином «допомагає» подолати спінову заборону, але це оточення є діамагнітним та спінзагадка все ж таки залишається. Деякі оксидази та оксигенази використовують парамагнітні іони металів як кофактор; у цьому разі спінову заборону формально знято. Нещодавно відкрито низку окислювальних ензимів, які не отримують кофактора. В роботі розглянуто бактеріальну 2,4-діоксигеназу, вільну від кофактора та її реакції з 2-n-алкіл-3-дигідрокси-4(1Н)хінолонами (АНХ). У статті ми надали результати квантово-хімічних розрахунків проміжного дирадикала, нещодавно запропонованого для прямої реакції кисню 3 АНХ-субстратами, та зробили заключення про механізм спін-каталізу.

К лючов і слов а: кисень, спінорбітальна взаємодія, кофакторнезалежна оксигеназа, супероксиданіон, триплет-синглетний перехід, бактеріальна 1-Н-3-гідрокси4-оксохінальдин 2,4-діоксигеназа, 2-n-метил-3дигідрокси-4(1Н)-хінолон, радикальна пара. 


\section{References}

1. Minaev BF. Spin effects in reductive activation of $\mathrm{O}_{2}$ by oxydase enzymes. RIKEN Rev. 2002; 44: 147-149.

2. Minaev BF. Electronic mechanisms of molecular oxygen activation. Russ Chem Rev. 2007; 76(7): 988-1010.

3. Minaev BF, Minaeva VA. Spin-dependent binding of dioxygen to heme and charge-transfer mechanism of spin-orbit coupling enhancement. Ukr Bioorg Acta. 2008; 2(1): 56-64.

4. Bugg TD. Oxygenases: mechanisms and structural motifs for $\mathrm{O}_{2}$ activation. Curr Opin Chem Biol. 2001; 5(5): 550-555.

5. Minaev BF. Electronic mechanisms of molecular oxygen bioactivation. Ukr Biokhim Zhurn. 2002; 74(3): 11-19. (In Russian).

6. Minaev BF. Environment friendly spin-catalysis for dioxygen activation. Chem Chem Technol. 2010; 4(1): 1-16.

7. Prabhakar R, Siegbahn PEM, Minaev BF, Ågren H. Activation of triplet dioxygen by glucose oxidase: spin-orbit coupling in the superoxide ion. J Phys Chem B. 2002; 106(14): 3742-3750.

8. Prabhakar R, Siegbahn PE, Minaev BF. A theoretical study of the dioxygen activation by glucose oxidase and copper amine oxidase. Biochim Biophys Acta. 2003; 1647(1-2): 173-178.

9. Minaev BF. Spin-catalysis in the processes of photo- and bioactivation of molecular oxygen. Ukr Biokhim Zhurn. 2009; 81(3): 21-45. (In Russian).

10. Minaev BF, Minaeva VO, Agren H. Spin-orbit coupling in enzymatic reactions and the role of spin in biochemistry. In: Leszczynski J, editor. Handbook of Computational Chemistry: Springer Netherlands. 2012; 1067-1093.

11. Bui S, Steiner RA. New insight into cofactor-free oxygenation from combined experimental and computational approaches. Curr Opin Struct Biol. 2016; 41: 109-118.

12. Hernandez-Ortega A, Quesne MG, Bui S, Heuts DP, Steiner RA, Heyes DJ, de Visser SP, Scrutton NS. Origin of the proton-transfer step in the cofactor-free (1H)-3-hydroxy-4oxoquinaldine 2,4-dioxygenase: effect of the basicity of an active site His residue. $J$ Biol Chem. 2014; 289(12): 8620-8632.

13. Hernández-Ortega A, Quesne MG, Bui S, Heyes DJ, Steiner RA, Scrutton NS, de
Visser SP. Catalytic mechanism of cofactor-free dioxygenases and how they circumvent spinforbidden oxygenation of their substrates. $J \mathrm{Am}$ Chem Soc. 2015; 137(23): 7474-7487.

14. Silva PJ. Refining the reaction mechanism of $\mathrm{O}_{2}$ towards its co-substrate in cofactor-free dioxygenases. Peer J. 2016; 4: e2805.

15. Steiner RA, Janssen HJ, Roversi P, Oakley AJ, Fetzner S. Structural basis for cofactorindependent dioxygenation of N-heteroaromatic compounds at the alpha/beta-hydrolase fold. Proc Natl Acad Sci USA. 2010; 107(2): 657-662.

16. Frerichs-Deeken U, Ranguelova K, Kappl R, Hüttermann J, Fetzner S. Dioxygenases without requirement for cofactors and their chemical model reaction: compulsory order ternary complex mechanism of 1H-3-hydroxy4-oxoquinaldine 2,4-dioxygenase involving general base catalysis by histidine 251 and single-electron oxidation of the substrate dianion. Biochemistry. 2004; 43(45): 1448514499.

17. Fetzner S, Steiner RA. Cofactor-independent oxidases and oxygenases. Appl Microbiol Biotechnol. 2010; 86(3): 791-804.

18. Thierbach S, Bui N, Zapp J, Chhabra SR, Kappl R, Fetzner S. Substrate-assisted $\mathrm{O}_{2}$ activation in a cofactor-independent dioxygenase. Chem Biol. 2014; 21(2): 217-225.

19. Baas BJ, Poddar H, Geertsema EM, Rozeboom HJ, de Vries MP, Permentier HP, Thunnissen AM, Poelarends GJ. Functional and structural characterization of an unusual cofactor-independent oxygenase. Biochemistry. 2015; 54(5): 1219-1232.

20. Shen B, Hutchinson CR. Tetracenomycin F1 monooxygenase: oxidation of a naphthacenone to a naphthacenequinone in the biosynthesis of tetracenomycin C in Streptomyces glaucescens. Biochemistry. 1993; 32(26): 6656-6663.

21. Silva PJ, Ramos MJ. A comparative densityfunctional study of the reaction mechanism of the $\mathrm{O}_{2}$-dependent coproporphyrinogen III oxidase. Bioorg Med Chem. 2008; 16(6): 27262733.

22. Massey V. Activation of molecular oxygen by flavins and flavoproteins. J Biol Chem. 1994; 269(36): 22459-22462.

23. Salikhov KM, Molin YuN, Sagdeev RZ, Buchachenko AL. Spin polarization and magnetic effects in radical reactions. Elsevier 
Amsterdam, Budapest: Akademiai Kiado, 1984. $419 \mathrm{p}$.

24. Usselman RJ, Hill I, Singel DJ, Martino CF. Spin biochemistry modulates reactive oxygen species (ROS) production by radio frequency magnetic fields. PLoS One. 2014; 9(3): e93065.

25. Becke AD. Density-functional thermochemistry. III. The role of exact exchange. J Chem Phys. 1993; 98(17): 5648-4652.

26. Granovsky AA. Firefly 8.0.0. system of codes. 2013. Available at http://classic.chem.msu.su/ gran/gamess/index.html.

27. Harvey JN, Aschi M, Schwarz H, Koch W. The singlet and triplet states of phenyl cation. A hybrid approach for locating minimum energy crossing points between non-interacting potential energy surfaces. Theor Chem Acc. 1998; 99(2); 95-99.
28. Hertwig RH, Koch W. On the accuracy of density functionals and their basis set dependence: An extensive study on the main group homonuclear diatomic molecules Li2 to Br2. J Comput Chem. 1995; 16(5): 576-585.

29. Schmidt MW, Baldridge KK, Boatz JA, Elbert ST, Gordon MS, Jensen JH, Koseki S, Matsunaga N, Nguyen KA, Su S, Windus TL, Dupuis M, Montgomery JA. General atomic and molecular electronic structure system. J Comput Chem. 1993; 14(11): 1347-1363.

30. Granovsky AA. Extended multi-configuration quasi-degenerate perturbation theory: the new approach to multi-state multi-reference perturbation theory. J Chem Phys. 2011; 134(21): 214113. 